\title{
3D-tiskani oralni dozirni oblici punjeni disperzijom ulja i djelatne tvari
}

\author{
A. Milićević, M. Gretić i G. Matijašić* \\ Fakultet kemijskog inženjerstva i tehnologije, Sveučilište u Zagrebu, \\ Marulićev trg 19, 10000 Zagreb
}

Ovo djelo je dano na korištenje pod Creative Commons Attribution 4.0

\begin{abstract}
Sažetak čitih čvrstih pripravaka. Rezultati ispitivanja oslobađanja djelatne tvari pokazali su profile oslobađanja s početnom vremenskom gođenim oslobađanjem.

Ključne riječi

3D-tisak, personalizirani lijekovi, odgođeno oslobađanje, profili oslobađanja, Peppas-Sahlinov model
\end{abstract}

U ovom radu ispitana je mogućnost izrade oralnih dozirnih oblika tehnologijom 3D-tiska. Printani oblici podvrgnuti su in vitro ispitivanju oslobađanja djelatne tvari a rezultati su obrađeni u dodatku za Microsoft Excel, DDSolver. Proizvedeno je šest razlizadrškom, funkcijski povezanom s debljinom stijenke oblika. Profili su dobro opisani Peppas-Sahlinovim modelom. Pokazano je da tehnologija 3D-tiska ima potencijal postati metodom za jednostavnu i brzu izradu personaliziranih dozirnih oblika s od-

\section{Uvod}

Tehnologija 3D-tiska nalazi rastuću primjenu u brojnim industrijama zbog brze i relativno povoljne izrade predmeta svih mogućih oblika i veličina upotrebom različitih materijala. U farmaceutskom sektoru ubraja se u revolucionarne trendove u razvoju farmaceutskih pripravaka. ${ }^{1} 2015$. godine pripravak za liječenje epilepsije, Spritam, američke tvrtke Aprecia Pharmaceuticals, postao je prvi lijek odobren od strane Američke agencije za hranu i lijekove (U. S. Food and Drug Administration, FDA) proizveden tom tehnologijom. Tada započinje povećan interes za proizvodnju različitih dozirnih oblika 3D-tiskom. Znanstvenici smatraju da 3D-tisak može dovesti do personalizacije liječenja i prilagođavanja dozirnih oblika potrebama pacijenata zbog mogućnosti brze i jednostavne proizvodnje lijekova s fleksibilnim dozama djelatne tvari..$^{2-4}$

Čvrsti oralni dozirni oblici zauzimaju najveći dio tržišta farmaceutske industrije i najbolje su primljeni kod pacijenata, no kako se većinom proizvode na konvencionalan način, postoje razne poteškoće vezane za njihov razvoj, proizvodnju i primjenu..$^{5,6} \mathrm{U}$ ranim fazama razvoja lijekova ključna je fleksibilnost doziranja. ${ }^{7}$ 3D-tisak omogućuje jednostavnu modifikaciju doza prilagođenih potrebama pacijenta promjenom dimenzija dozirnih oblika ili gustoćom njihove ispune. Također je moguće ispunjavati individualne želje pacijenata po pitanju boje i oblika, što stvara bolju percepciju lijeka bolesniku, ${ }^{8}$ a posebno je korisno u liječenju djece. ${ }^{9}$

Lim i sur. ${ }^{10}$ ističu da su tradicionalne metode proizvodnje dozirnih oblika znatno povoljnije za masovnu proizvodnju. Međutim, pri proizvodnji manjih količina ukupni fiksni troškovi tradicionalne proizvodnje znatno doprinose jediničnoj cijeni proizvoda zbog čega 3D-tisak postaje ekonomski isplativija tehnologija proizvodnje. Upravo u

*Autor za dopisivanje: prof. dr. sc. Gordana Matijašić,

e-pošta: gmatijas@fkit.hr tom dijelu očituje se mogućnost personaliziranog liječenja. Implementacijom tehnologije 3D-tiska mogla bi se znatno smanjiti potrošnja resursa u proizvodnji dozirnih oblika te bi se taj obično dugotrajan proces mogao znatno skratiti implementacijom proizvodnje u ljekarne ili bolnice. Preis i Öblom ${ }^{9}$ vide dva načina implementacije proizvodnje nakon dijagnoze postavljene od liječnika: I) dizajn dozirnog oblika, proizvodnja i distribucija se odvijaju u ljekarni; II) dizajn dozirnog oblika priprema se u ljekarni a potom šalje na tisak u vanjsku instituciju koja vraća gotov proizvod u ljekarnu. U oba slučaja sirovina se dobavlja od treće strane a ljekarna distribuira proizvod pacijentu. Najveći izazovi javljaju se oko kontrole kvalitete, kako osnovne sirovine tako i gotovog proizvoda. Američka agencija za hranu i lijekove (FDA) prepoznala je rastući trend primjene 3D-tiska u farmaceutskoj industriji i medicini, te stoga radi upravo na razvoju regulatornih direktiva koje će riješiti novonastala pitanja.

Aditivna proizvodnja omogućuje proizvodnju predmeta svih oblika i veličina nanošenjem slojeva materijala. Nekoliko je različitih tehnologija aditivne proizvodnje koje se razlikuju prema principu rada i vrsti materijala kojima se koriste. Nekim se metodama materijali tale ili omekšavaju, npr. taložno srašćivanje (engl. Fused Deposition Modeling, FDM), selektivno lasersko taljenje (engl. Selective Laser Melting, SLM) i selektivno lasersko sinteriranje (engl. Selective Laser Sintering, SLS), dok druge metode očvršćuju tekuće materijale, npr. stereolitografija (engl. Stereolithography, SLA). S obzirom na način dobivanja slojeva, tehnike aditivne proizvodnje svrstavaju se u pet osnovnih skupina: laserski bazirani procesi, procesi ekstrudiranja, procesi izbijanja materijala, procesi prianjanja materijala i procesi u kojima se rabi zraka elektrona. ${ }^{11,12}$ Najveću primjenu u farmaceutskoj industriji nalazi tehnologija taložnog srašćivanja, međutim, kao jedan od glavnih nedostataka te tehnologije navodi se visoka temperatura potrebna za obradu termoplastičnih polimera. Kada je djelatna tvar ugrađena u polimernu matricu, prolazi isti postupak obrade prilikom 3D-tiska kao i sam polimer. Za toplinski osjetljive 
djelatne tvari to su nepovoljni uvjeti koji dovode do degradacije lijeka. Pokazalo se povoljnim tom tehnologijom tiskati spremišne sustave različitih oblika koji se onda pune praškastom djelatnom tvari. ${ }^{13,14} \mathrm{U}$ ovom radu dizajnirani su različiti čvrsti oralni dozirni oblici koji su izrađeni tehnologijom 3D-tiska. Tijekom tiska proces je pauziran na određenim visinama/slojevima, dozirni oblik napunjen je uljnom disperzijom djelatne tvari i potom zatvoren nastavljanjem tiska. Prednosti takvog načina izrade su: jednostavnost punjenja uljnom disperzijom, mogućnost modificiranja doze promjenom koncentracije disperzije, nema potrebe za dizajnom kompliciranih spremišnih sustava koji se zatvaraju, postupak izrade odvija se u jednom ciklusu tisak-punjenje-tisak.

\section{Eksperimentalni dio}

\subsection{Materijali}

Disperzije koncentracije $1200 \mathrm{mg} \mathrm{l}^{-1}$ pripremljene su od djelatne tvari dronedaron-hidroklorida za liječenje srčane aritmije $^{15}$ (PLIVA Hrvatska d. o. o.) te ulja Labrafil M1944CS (Oleoil polioksil-6 glicerid) proizvođača Gattefosse. Dozirni oblici tiskani su upotrebom poli(vinil-alkohol) (PVA) filamenta tvrtke Technology Outlet.

Dronedaron-hidroklorid odabran je kao modelna djelatna tvar kojom se simulira oslobađanje iz dozirnih oblika različite geometrije i debljine stijenki. Labrafil M1944CS često se upotrebljava u farmaceutskoj industriji za povećanje bioraspoloživosti djelatnih tvari slabo topljivih u vodi. Upo- trijebljen je za pripremu disperzije djelatne tvari, čime je omogućeno jednostavnije punjenje 3D-tiskanog dozirnog oblika izravno pomoću šprice. PVA filament čest je u pripremi dozirnih oblika 3D-tiskom budući da je to farmaceutski prihvatljiv polimer, a ujedno i komercijalno dostupan. Komercijalno tiskanje dozirnih oblika zahtijevalo bi ipak kontrolu kvalitete i porijekla materijala za tisak.

\subsection{Izrada računalnih modela}

U programu FreeCAD izrađena su četiri različita oblika (KAP, TAB A, TAB B i PEZ) iste debljine stijenki $(0,750 \mathrm{~mm})$ prikazana na slici 1 . Dodatno su izrađena još dva modela KAP čije su debljine stijenki iznosile 1,125 mm i 1,500 mm. $U$ istraživanju je ispitan utjecaj različitih geometrija dozirnih oblika na oslobađanje djelatne tvari. Utjecaj debljine stijenke ispitan je modificiranjem modela KAP. Na slici 1 prikazani su računalni modeli dozirnih oblika. Prilikom pripreme za tisak, ovisno o obliku, definiran je sloj na kojem će se tisak pauzirati u svrhu doziranja smjese ulja i djelatne tvari. Na slici 1 prikazane su postotne visine dobivene dijeljenjem definiranog sloja ukupnim brojem slojeva za svaki oblik.

\subsection{Izvedba 3D-tiska}

Priprema za tisak dozirnih oblika provedena je u programu FlashPrint. U tablici 1 prikazane su postavke 3D-printera FlashForge Inventor I čiji je princip rada taložno srašćivanje. Na slici 1 za svaki od modela prikazani su postotci tiska na kojima je izvedeno pauziranje printa radi punjenja.

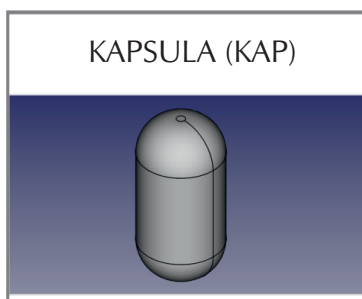

a) $d=0,750 \mathrm{~mm}$

b) $d=1,125 \mathrm{~mm}$

c) $d=1,500 \mathrm{~mm}$
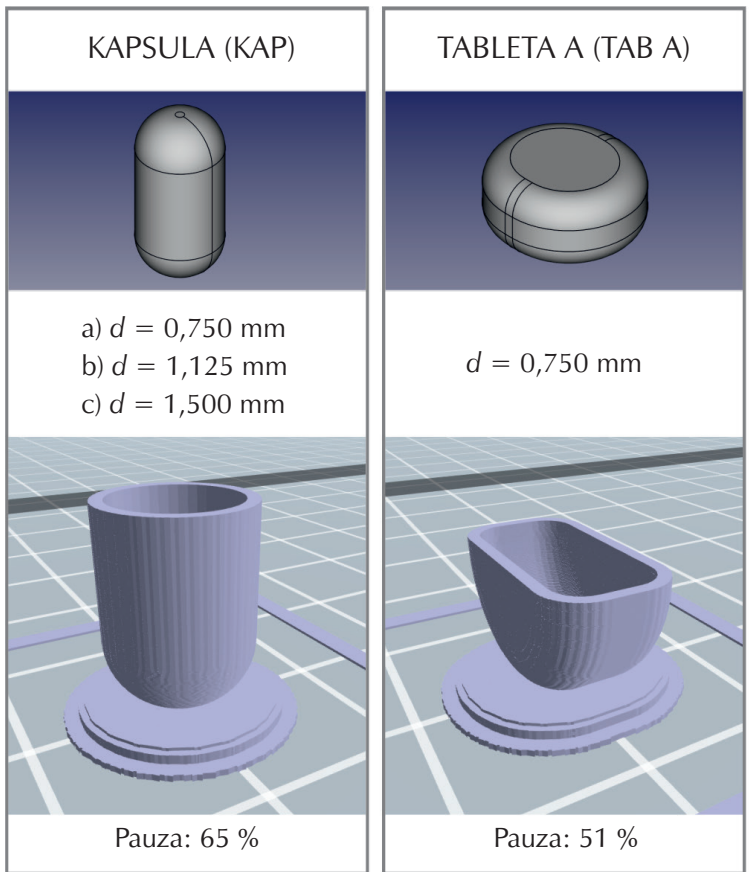

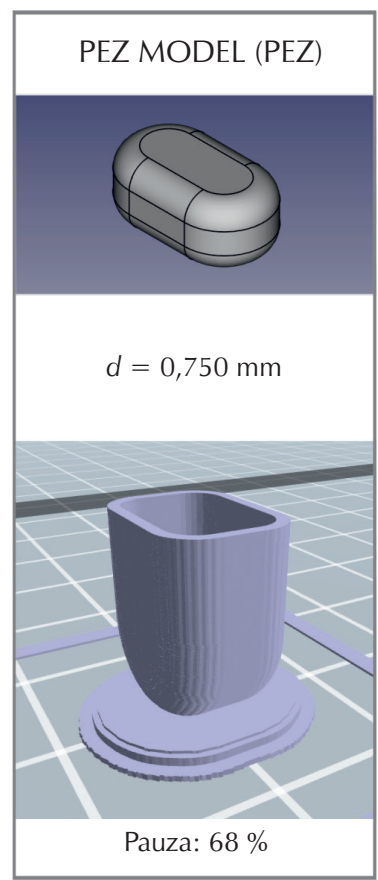

Pauza: $79 \%$
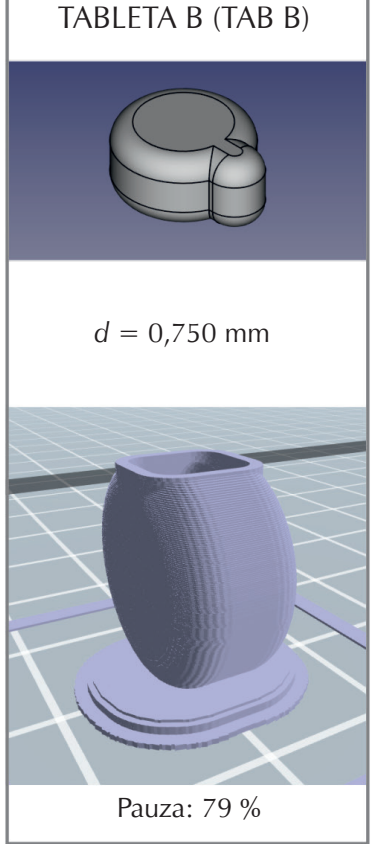

Pauza: $68 \%$

Slika 1 - Pregled izrađenih računalnih modela i postotak printa na kojem je provedeno zaustavljanje i doziranje za pojedini model

Fig. 1 - Review of computer-designed models and percentage during which the print is paused and dosage is performed for each of the models 
Tablica 1 - Postavke printa za sve modele

Table 1 - Printing preferences for all models

\begin{tabular}{|c|c|}
\hline Rezolucija & visoka \\
\hline Podloga & da \\
\hline Visina sloja & $0,10 \mathrm{~mm}$ \\
\hline Ispuna & linijska, $100 \%$ \\
\hline Brzina printa & $20 \mathrm{~mm} \mathrm{~s}^{-1}$ \\
\hline Temperatura mlaznice & $185^{\circ} \mathrm{C}$ \\
\hline Temperatura podloge & $50{ }^{\circ} \mathrm{C}$ \\
\hline
\end{tabular}

\subsection{Metode karakterizacije}

\subsubsection{Određivanje sadržaja dronedarona}

Sadržaj dronedarona u smjesi ulja i dronedarona određen je gravimetrijskom metodom; šprica za doziranje uljne disperzije vagana je prije i poslije doziranja na analitičkoj vagi. Masa dronedarona izračunata je na temelju poznatih udjela komponenata u smjesi.

\subsubsection{Ispitivanje brzine oslobađanja dronedarona}

Brzina oslobađanja dronedarona iz tiskanih oblika ispitana je metodom in vitro, a upotrijebljen je uređaj $R C-6 D$, Zhengzhou Nanbei Instrument. Uvjeti eksperimenta prikazani su u tablici 2. Pri izvedbi eksperimenata upotrijebljene su tzv. japanske košarice za potapanje pomoću kojih je osigurana uronjenost oblika u medij kako bi bili izloženi najpovoljnijim hidrodinamičkim uvjetima tijekom cijelog mjerenja.

Tablica 2 - Uvjeti in vitro ispitivanja oslobađanja prema FDA metodi $^{16}$

Table 2 - In vitro dissolution test conditions according to FDA method $^{16}$

\begin{tabular}{|c|c|}
\hline Medij & Fosfatni pufer \\
\hline $\mathrm{pH}$ & 4,5 \\
\hline Volumen & $1 \mathrm{I}$ \\
\hline Temperatura & $37 \pm 0,5^{\circ} \mathrm{C}$ \\
\hline USP apartura & 2 (lopatice) \\
\hline Broj okretaja & $75{\text { o } \min ^{-1}}^{-1}$ \\
\hline Vrijeme uzorkovanja & $10,15,20,30,45,60,90,120 \mathrm{~min}$ \\
\hline
\end{tabular}

Uzorci su filtrirani pomoću filtra Chromafil Xtra H-PTFE-45/25 veličine pora od $0,45 \mu \mathrm{m}$ i analizirani na UV/Vis spektrofotometru Shimadzu UV-1280 pri valnoj duljini $289,8 \mathrm{~nm}$, što odgovara maksimumu apsorbancije dronedarona u fosfatnom puferu. Kako bi se utvrdila valna duljina pri kojoj se postiže maksimalna apsorbancija, pripremljena je otopina dronedarona u puferu koncentracije
$10 \mathrm{mg} \mathrm{ml}^{-1}$. UV-Vis spektrofotometrom snimljen je spektar u području valnih duljina od 200 do $400 \mathrm{~nm}$ na temelju kojeg je utvrđena valna duljina od 289,8 nm, pri kojoj se postiže maksimalna apsorbancija. Za analizu je upotrijebljena protočna kiveta od kvarca. Koncentracije su izračunate na temelju pripremljenog umjernog pravca.

\subsection{Obrada podataka}

Podatci dobiveni ispitivanjem brzine oslobađanja obrađeni su u besplatnom dodatku za Microsoft Excel, DDSolver. ${ }^{17}$

Tri su metode pristupa analizi kinetike oslobađanja sadržane u DDSolver-u: statističke metode, metode ovisne o modelu i metode neovisne o modelu. Metode ovisne o modelu dobivene su iz empirijskih korelacija s provedenim eksperimentima u kojima se nalaze parametri koji ukazuju na sama svojstva oslobađanja djelatne tvari te omogućuju procjenu konstante brzine oslobađanja. Statističke metode i metode neovisne o modelu dobivene su potpuno statističkim i numeričkim postupcima izrade modela.

Peppas-Sahlinov model spada u metodu procjene kinetičkih parametara oslobađanja na temelju empirijskog modela prikazanog jedn. (1): ${ }^{18,19}$

$$
\frac{C}{C_{0}}=k_{1} t^{m}+k_{2} t^{2 m}
$$

Nekoliko je inačica Peppas-Sahlinova modela ugrađeno u DDSolver. ${ }^{17}$ Uzme li se vrijednost parametra $m=0,5$ i doda li se vremenska zadrška $\left(T_{\text {lag }}\right)$ u jedn. (1), izraz prelazi u sljedeći oblik:

$$
\frac{C}{C_{0}}=k_{1}\left(t-T_{\text {lag }}\right)^{0,5}+k_{2}\left(t-T_{\text {lag }}\right)
$$

Taj model označen je u DDSolveru kao Peppas-Sahlinov 2 model s vremenskom zadrškom.

Peppas-Sahlinov model odabran je zbog mogućnosti procjene mehanizama oslobađanja. U prikazanom modelu dan je doprinos Fickove i ne-Fickove difuzije oslobađanju djelatne tvari. ${ }^{18,19}$ Doprinos Fickove difuzije može se izračunati na temelju konstanti modela: ${ }^{20}$

$$
F=\frac{1}{1+\frac{k_{2}}{k_{1}} \cdot t^{m}}
$$

Za procjenu valjanosti modela korišten je korelacijski koeficijent $R_{\mathrm{p}}$ :

$$
R_{p}^{2}=1-\frac{(n-1)}{(p-1)}\left(1-R^{2}\right)
$$

Usporedba profila oslobađanja provedena je i metodom neovisnom o modelu koja se zasniva na izračunu faktora razlike $\left(f_{1}\right): 21$ 


$$
f_{1}=\left\{\frac{\left[\sum_{t=1}^{n}\left(R_{t}-T_{t}\right)\right]}{\sum_{t=1}^{n} R_{t}}\right\} \cdot 100
$$

Faktor razlike upućuje na različitost eksperimentalnog profila oslobađanja $\left(T_{t}\right)$ u usporedbi s referentnim uzorkom $\left(R_{\mathrm{t}}\right)$.

\section{Rezultati i rasprava}

Cilj ovog istraživanja bio je izrada različitih dozirnih oblika tehnologijom 3D-tiska, doziranje djelatne tvari tijekom same izrade modela - zaustavljanjem i nastavljanjem 3D-tiska te ispitivanje kinetike oslobađanja djelatne tvari iz dobivenih dozirnih oblika.

\subsection{D-tisak}

Glavni izazov pri izradi oblika tehnologijom taložnog srašćivanja bio je nastavljanje tiska nakon zaustavljanja. Elastični polimer koji neprekinuto teče iz visokotemperaturne mlaznice, prilikom zaustavljanja je formirao nit tzv. filamenta koju je bilo potrebno odstraniti. U slučaju da se ta nit ne uklanja, zatvaranje dozirnog oblika nastavkom tiskanja je neuspješno. Svaka nepravilnost ili ostatak prepreka su dobrom zatvaranju kapsule. Nadalje, opaženo je kako je potrebno izvesti zaustavljanje i nastavljanje tiska u što kraćem vremenu kako temperatura mlaznice ne bi počela padati. U tom slučaju dolazi do smanjenja tecivosti polimera što uzrokuje nehomogen tok rastaljenog filamenta. Dozirni oblici zaustavljani su na određenoj visini/sloju kako je prikazano na slici 1 te su u tom trenutku punjeni disperzijom dronedarona u ulju. Disperzija je dozirana u kapsule pomoću šprice. Volumeni punjenja prikazani su u tablici 3, a s obzirom na male volumene punjenje kapsula trajalo je do nekoliko sekundi. Odabrana je koncentracija disperzije od $1200 \mathrm{mgl}^{-1}$. Pri toj koncentraciji viskoznost disperzije još uvijek omogućuje tečenje smjese pod pritiskom kroz otvor šprice, što olakšava samo doziranje. Izmjerena viskoznost disperzije pri $30{ }^{\circ} \mathrm{C}$ iznosi 1,85 Pas. Opaženo je i kako je nastavak tiska uspješan samo ako su stijenke pri sloju na kojem se odvija zaustavljanje vertikalne i dva susjedna sloja se dodiruju u potpunosti cijelom površinom. Iz tog je razloga bilo potrebno modificirati model tablete tako što je dodan sloj s vertikalnim stijenkama dužine $1 \mathrm{~mm}$ na sredini modela (model TAB A, slika 1 ) ili otvor u obliku čepa s vertikalnim stijenkama duljine $1 \mathrm{~mm}$ (model TAB B, slika 1). To je uzrok razlici sadržaja dronedarona (tablica 3) između ta dva modela približno iste geometrije (oba modela imaju isti unutarnji volumen, $850 \mathrm{~mm}^{3}$ ). Tisak je u modelu TAB A zaustavljen na $51 \%$ visine, a u modelu TAB B na $79 \%$. Zahvaljujući položaju zaustavnog sloja, u model TAB B dozirana je dvostruko veća količina disperzije, a time i dronedarona. Nakon tiska kapsulama je ručno uklonjen početni sloj koji je služio kao podloga. Otisnute kapsule prikazane su na slici 2 .

\subsection{Kinetika oslobađanja}

3D-tiskanjem su dobivena po tri uzorka svakog od modela prikazanog na slici 2. Provedena su ispitivanja in vitro te je, na temelju određenih koncentracija i početne koncentracije dronedarona, izračunat udio otpuštenog dronedarona u vremenu te prikazan kroz profile oslobađanja (slike 3a i $3 b)$. Početne koncentracije određene su na temelju mase dronedarona dozirane u pojedini oblik, a prikazane su u tablici 3.

Analizom nastalih profila može se uočiti sličnost oblika krivulja oslobađanja:

- početno razdoblje, u kojem nema oslobađanja je tzv. razdoblje odgode $\left(T_{\mathrm{lag}}\right)$, a razlikuje se ovisno o debljini stijenke i geometriji modela;

- razdoblje difuzije, koji se očituje u pojavi niskih koncentracija uzrokovanih mehanizmom difuzije dronedarona kroz nabubrene polimerne lance;

- razdoblje erozije, u kojem dolazi do naglog porasta koncentracije uzrokovanog razaranjem polimera.
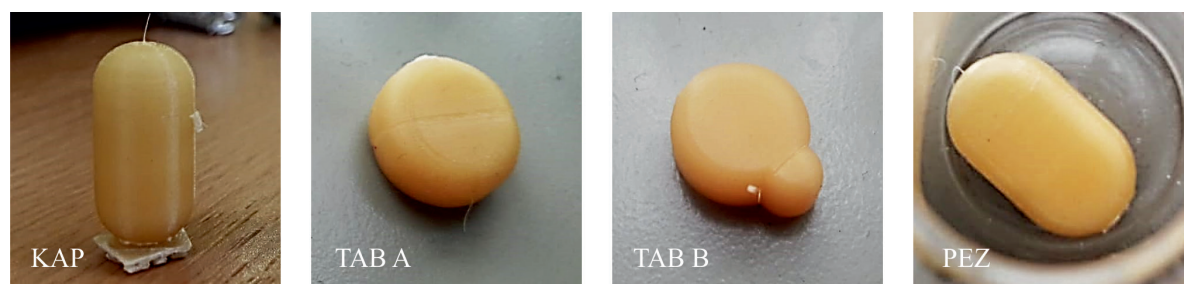

Slika 2 - Fotografije otisnutih i napunjenih dozirnih oblika

Fig. 2 - Photographs of printed and filled dosage forms

Tablica 3 - Masa dronedarona sadržana u dozirnim oblicima i ukupni volumen dozirane disperzije Table 3 - Weight of dronedarone in dosage forms and total volume of dispersion

\begin{tabular}{c|c|c|c|c|c|c}
\hline Model & KAP 0,750 & KAP 1,125 & KAP 1,500 & TAB A & TAB B & PEZ \\
\hline masa & $259 \mathrm{mg}$ & $259 \mathrm{mg}$ & $259 \mathrm{mg}$ & $213 \mathrm{mg}$ & $412 \mathrm{mg}$ & $386 \mathrm{mg}$ \\
\hline volumen & $216 \mathrm{ml}$ & $216 \mathrm{ml}$ & $216 \mathrm{ml}$ & $178 \mathrm{ml}$ & $343 \mathrm{ml}$ & $322 \mathrm{ml}$ \\
\hline
\end{tabular}


Ispitivanja in vitro provedena su u razdoblju od tri sata. Tijekom navedenog razdoblja udio otpuštenog dronedarona kreće se u rasponu od 80 do $90 \%$ za sve modele čija je stijenka debljine 0,750 mm. Kod modela KAP uočeno je da povećanjem debljine stijenke od 0,750 do 1,500 mm udio otpuštenog dronedarona nakon tri sata opada s $90 \%$ na svega 50 \%. To je posljedica duljine početnog razdoblja koje je u izravnoj vezi s debljinom stijenke dozirnog oblika. ${ }^{22}$

Utjecaj početne koncentracije dronedarona na brzinu oslobađanja ispitan je usporedbom profila za modele TAB A i TAB B. Sadržaj dronedarona u modelu TAB B iznosi $412 \mathrm{mg}$, a u modelu TAB A $213 \mathrm{mg}$. Profil oslobađanja TAB A uzet je kao referenta vrijednost, a izračunato je odstupanje profila TAB B od modela TAB A. Na temelju jedn. (5) izračunat je faktor razlike čija je vrijednost 8,52 \%. U slučaju kada je faktor razlike manji od $15 \%$, promatrani profili smatraju se neznatno različitima, odnosno odstupanje eksperimentalnog profila od referentnog je u dopuštenim granicama i prihvatljivo je. ${ }^{21,23}$ Time se može zaključiti da gotovo dvostruko veća početna koncentracija dronedarona nema znatan utjecaj na brzinu njegova oslobađanja.

Profili oslobađanja opisani su Peppas-Sahlinovim 2 modelom (jedn. 2) koji uključuje i tzv. razdoblje odgode $\left(T_{\text {lag }}\right)$, odnosno početno razdoblje ispitivanja u kojem oslobađanje još nije započelo. Procijenjeni parametri modela navedeni su u tablici 4.

Na temelju korelacijskog koeficijenta može se zaključiti kako Peppas-Sahlinov model dobro opisuje sve profile oslobađanja. Prednost tog modela je mogućnost procjene mehanizma oslobađanja. U prikazanoj jedn. (1) prvi član predstavlja doprinos mehanizma difuzije, dok drugi član označava doprinos relaksacije polimerne matrice. ${ }^{19-21} \mathrm{U}$ tablici 4 prikazane su izračunate vrijednosti $F$ parametra (jedn. 3) koji ukazuje na doprinos Fickove difuzije u oslobađanju djelatne tvari. ${ }^{21}$ Najmanje vrijednosti dobivene su kod modela KAP 0,750 mm. Veće vrijednosti pokazuju znatniju prisutnost mehanizma Fickove difuzije koji postaje sve izraženiji porastom debljine stijenke te kod nepravilnijih oblika (TAB, PEZ). Difuzijski je mehanizam izraženiji kod svih oblika, osim onog najpravilnijeg s najtanjom stijenkom (KAP 0,750 mm). Oslobađanje dronedarona iz dozirnog oblika KAP $0,750 \mathrm{~mm}$ kontrolirano je relaksacijom polimerne matrice. Na slikama 4(a-f) prikazana je usporedba srednjih eksperimentalnih vrijednosti uzoraka svih oblika i Peppas-Sahlinova 2 modela. Unatoč visokim vrijednostima korelacijskog koeficijenta (tablica 4), na sli-
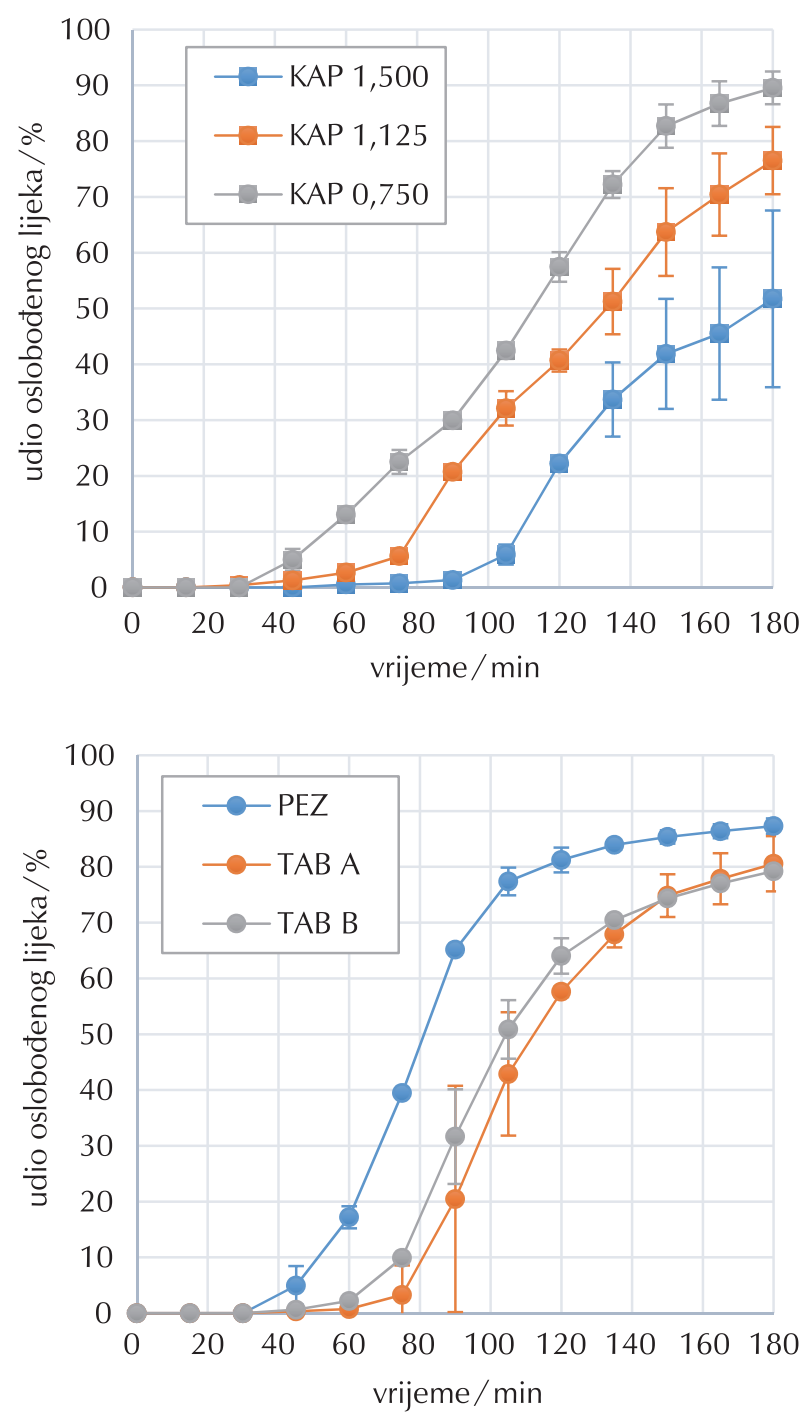

Slika 3 - Srednji profili oslobađanja dobiveni ispitivanjem a) modela KAPSULA; b) PEZ modela te modela TABLETA A i B

Fig. 3 - Mean dissolution profiles of a) CAPSULE models, b) models PEZ, CAPSULE A and B

kama 4(a-f) može se uočiti nedostatak Peppas-Sahlinova modela. Početno razdoblje difuzije djelatne tvari nije u potpunosti dobro opisano, model ne predviđa postupno povećanje koncentracije.

Tablica 4 - Procijenjeni parametri Peppas-Sahlinova modela i doprinos mehanizma Fickove difuzije Table 4 - Estimated parameters of the Peppas-Sahlin model and contribution of Fickian diffusion mechanism

\begin{tabular}{c|c|c|c|c|c|c}
\hline Model & KAP 0,750 & KAP 1,125 & KAP 1,500 & TAB A & TAB B & PEZ \\
\hline$k_{1}, \min ^{-0,5}$ & 0,108 & 3,381 & 5,892 & 12,400 & 10,685 & 14,762 \\
\hline$k_{2}, \min ^{-1}$ & 0,688 & 0,405 & 0,007 & $-0,404$ & $-0,264$ & $-0,606$ \\
\hline$T_{\text {lag, }} \min$ & 40,8 & 73,1 & 104,0 & 87,1 & 74,2 & 58,7 \\
\hline$R_{\mathrm{p}}{ }^{2}$ & 0,990 & 0,998 & 0,998 & 0,998 & 0,994 & 0,990 \\
\hline$F$ & 0,012 & 0,384 & 0,984 & 1,777 & 1,496 & 2,226 \\
\hline
\end{tabular}



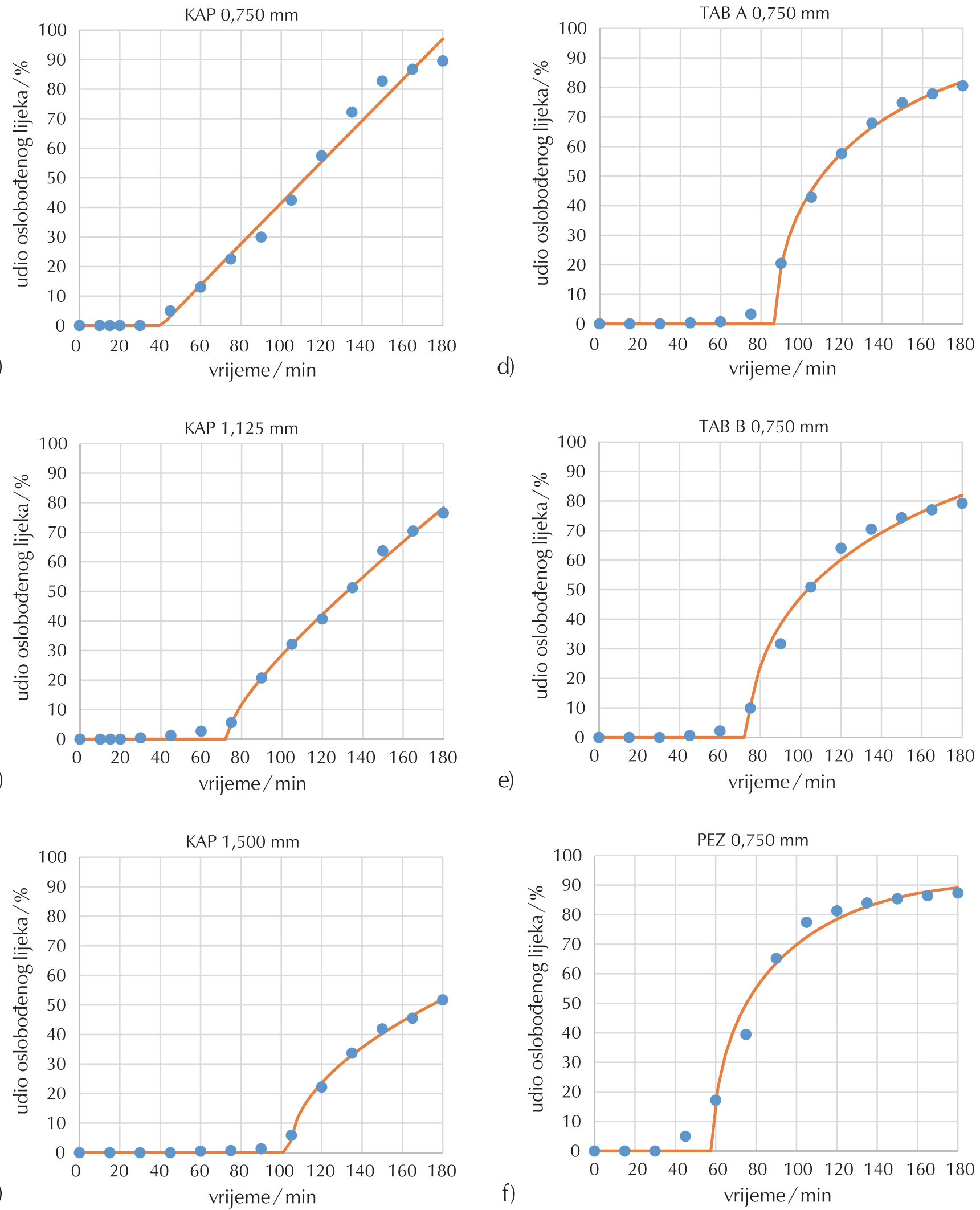

Slika 4 - Usporedba eksperimentalnih vrijednosti i izračunatih na temelju modela: a) KAP 0,750 mm, b) KAP 1,125 mm, c) KAP 1,500 mm, d) TAB A 0,750 mm, e) TAB B 0,750 mm, f) PEZ 0,750 mm

Fig. 4 - Comparison of experimental and model values: a) KAP 0,750 mm, b) KAP 1,125 mm, c) KAP 1,500 mm, d) TAB A 0,750 mm, e) TAB B 0,750 mm, f) PEZ 0,750 mm 
Vrijednosti vremenske zadrške dobivene eksperimentalno (minimalne i maksimalne vrijednosti u 3 mjerenja) i one procijenjene na temelju Peppas-Sahlinova modela prikazane su u ovisnosti o debljini stijenke na slici 5. Vidljivo je kako su vrijednosti dobivene Peppas-Sahlinovim modelom veće od eksperimentalnih, što je posljedica neprikladnosti modela za opis razdoblja difuzije, kako je već ranije navedeno. Cijelo područje manjih koncentracija taj model vidi kao razdoblje u kojem nema oslobađanja i zbog toga su vrijednosti razdoblja odgode veće od realnih. No vrijednosti odgovaraju vremenu u kojem koncentracija počinje naglo rasti, te bi se podatci dobiveni tim modelom mogli rabiti za procjenu trenutka oslobađanja djelatne tvari. Rješenje za opis razdoblja difuzije bio bi jedan od empirijskih modela. Makoid i sur. ${ }^{24}$ su u svojem radu modificirali Weibullov i Makoidov model tako da dobro opisuju početno razdoblje profila oslobađanja. Međutim, ističu da je za opis eksperimentalnih podataka uvijek bolje primjenjivati manje kompleksan model ukoliko početno razdoblje nije od velike važnosti za samo oslobađanje, a što općenito ovisi o vrsti pripravka i vrsti djelatne tvari. Pokazali su da parametri empirijskih modela nemaju fizikalni smisao. Zbog svega navedenog, Peppas-Sahlinov model dobar je odabir za opis profila oslobađanja dronedarona iz 3D-tiskanih oblika.

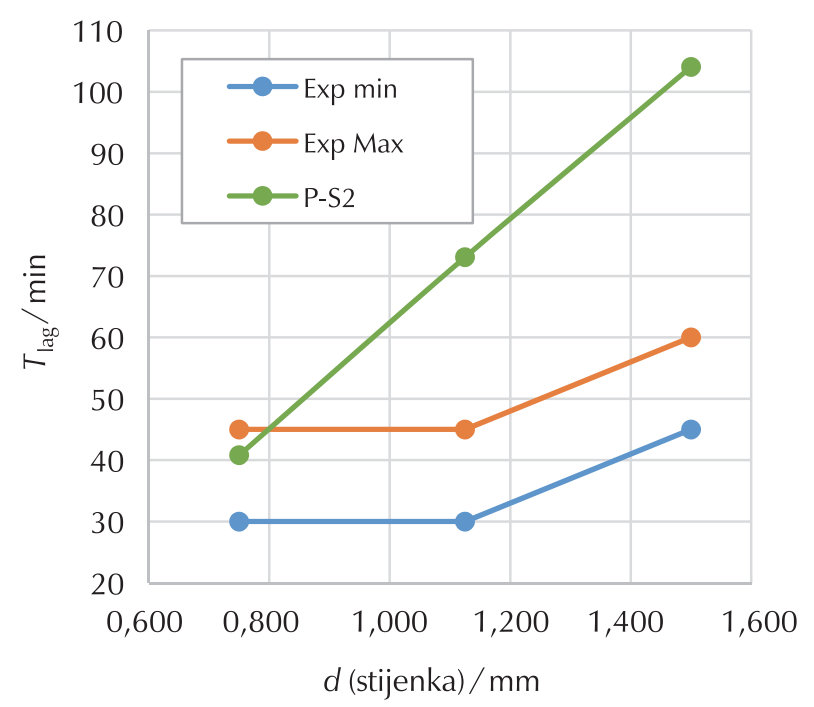

Slika 5 - Ovisnosti vremenske zadrške o debljini stijenke Fig. 5 - Time lag as a function of wall thickness

\section{Zaključak}

Tehnologijom 3D-tiska taložnim srašćivanjem uspješno su izrađeni dozirni oblici različite geometrije u koje je doziran dronedaron-hidroklorid u uljnoj disperziji uz zaustavljanje i nastavljanje tiska.

Profile oslobađanja dronedarona iz printanih oblika moguće je dobro opisati primjenom Peppas-Sahlinova modela $\mathrm{s}$ vremenskom zadrškom. Procjenom parametara može se zaključiti kako doprinos difuzijskog mehanizma nad relak- sacijskim raste porastom debljine stijenke i kompleksnosti geometrije. Vrijednosti vremenske zadrške procijenjene Peppas-Sahlinovim modelom pokazuju linearan trend $u$ odnosu na debljinu stijenke, što znači da je moguće postići željenu odgodu oslobađanja djelatne tvari definiranjem debljine stijenke prilikom modeliranja.

Nadalje, pomoću faktora razlike dokazano je kako do dva puta veća početna koncentracija dronedarona nema znatan utjecaj na brzinu oslobađanja.

Uzevši u obzir sve navedeno, može se zaključiti kako bi ta metoda mogla biti dobra podloga za jednostavnu i brzu izradu personaliziranih dozirnih oblika s odgođenim oslobađanjem.

\section{Popis simbola \\ List of symbols}

d - debljina stijenke, $\mathrm{m}$

- wall thickness, $\mathrm{m}$

c - koncentracija u vremenu $t, \mathrm{~kg} \mathrm{~m}^{-3}$

- concentration in time $t, \mathrm{~kg} \mathrm{~m}^{-3}$

$c_{0} \quad$ - početna koncentracija, $\mathrm{kg} \mathrm{m}^{-3}$

- initial concentration, $\mathrm{kg} \mathrm{m}^{-3}$

$F \quad$ - doprinos Fickove difuzije u oslobađanju djelatne tvari

- contribution of Fickian diffusion in drug release

$k_{1}$ - konstanta oslobađanja 1 Peppas-Sahlinova 2 modela, $\mathrm{s}^{-0,5}$ - dissolution constant 1 in Peppas-Sahlin model, $\mathrm{s}^{-0,5}$

$k_{2} \quad$ - konstanta oslobađanja 2 Peppas-Sahlinova 2 modela, $\mathrm{s}^{-1}$ - dissolution constant 2 in Peppas-Sahlin model, $\mathrm{s}^{-1}$

$T_{\text {lag }}-$ vremenska zadrška, $\mathrm{s}$

- lag time, $s$

n $\quad$ - broj parametara modela

- number of model parameters

p - broj eksperimentalnih podataka

- number of experimental data

$R_{\mathrm{p}}{ }^{2}-$ korelacijski koeficijent

- correlation coefficient

\section{Literatura \\ References}

1. A. W. Basit, S. Gaisford, 3D printing of pharmaceuticals, AAPS Advances in the Pharmaceutical Sciences Series, Cham, Switzerland, 2018.

2. S. J. Trenfield, C. M. Madla, A.W. Basit, S. Gaisford, The shape of things to come: Emerging applications of 3D printing in healthcare, u: 3D Print. Pharm., Springer, Cham, 2018., str. 1-19. doi: https://doi.org/10.1007/978-3-319-90755-0_1.

3. J. Norman, R. D. Madurawe, C. M. V. Moore, M. A. Khan, A. Khairuzzaman, A new chapter in pharmaceutical manufacturing: 3D-printed drug products, Adv. Drug Deliv. Rev. 108 (2017) 39-50, doi: https://doi.org/10.1016/j. addr.2016.03.001.

4. M. A. Alhnan, T. C. Okwuosa, M. Sadia, K.-W. Wan, W. Ahmed, B. Arafat, Emergence of 3D printed dosage forms: opportunities and challenges, Pharm. Res. 33 (2016) $1817-$ 
1832, doi: https://doi.org/10.1007/s11095-016-1933-1.

5. M. E. Aulton, K. Taylor, Aulton's pharmaceutics: the design and manufacture of medicines, Churchill Livingstone/Elsevier, 2013.

6. L. V. Allen, H. C. Ansel, Ansel's pharmaceutical dosage forms and drug delivery systems, Wolters Kluwer, 2014.

7. E. Kwong, Oral formulation roadmap from early drug discovery to development, John Wiley \& Sons, Inc., Hoboken, NJ, USA, 2017, doi: https://doi.org/10.1002/9781118907894.

8. A. W. Basit, M. Orlu, M. Scarpa, S. Gaisford, A. Goyanes, M. Kamlow, Patient acceptability of 3D printed medicines, Int. J. Pharm. 530 (2017) 71-78, doi: https://doi.org/10.1016/j. ijpharm.2017.07.064.

9. M. Preis, H. Öblom, 3D-printed drugs for children - Are we ready yet?, AAPS PharmSciTech. 18 (2017) 303-308, doi: https://doi.org/10.1208/s12249-016-0704-y.

10. S. H. Lim, H. Kathuria, J.J.Y. Tan, L. Kang, 3D printed drug delivery and testing systems - a passing fad or the future? Adv. Drug Deliv. Rev. 132 (2018) 139-168, doi: https://doi. org/10.1016/j.addr.2018.05.006.

11. H. Bikas, P. Stavropoulos, G. Chryssolouris, Additive manufacturing methods and modelling approaches: a critical review, Int. J. Adv. Manuf. Technol. 83 (2016) 389-405, doi: https:// doi.org/10.1007/s00170-015-7576-2.

12. S. J. Trenfield, A. Awad, A. Goyanes, S. Gaisford, A. W. Basit, 3D printing pharmaceuticals: Drug development to frontline care, Trends Pharmacol. Sci. 39 (2018) 440-451, doi: https://doi.org/10.1016/j.tips.2018.02.006.

13. A. Melocchi, F. Parietti, G. Loreti, A. Maroni, A. Gazzaniga, L. Zema, 3D printing by fused deposition modeling (FDM) of a swellable/erodible capsular device for oral pulsatile release of drugs, J. Drug Deliv. Sci. Technol. 30 (2015) 360-367, doi: https://doi.org/10.1016/J.JDDST.2015.07.016.

14. A. Maroni, A. Melocchi, F. Parietti, A. Foppoli, L. Zema, A. Gazzaniga, 3D printed multi-compartment capsular devices for two-pulse oral drug delivery, J. Control. Release. 268 (2017) 10-18, doi: https://doi.org/10.1016/J.JCONREL.2017.10.008.
15. F. Iram, S. Ali, A. Ahmad, S. A. Khan, A. Husain, A review on dronedarone: Pharmacological, pharmacodynamic and pharmacokinetic profile, J. Acute Dis. 5 (2016) 102-108, doi: https://doi.org/10.1016/j.joad.2015.10.002.

16. Food and Drug Administration, Dissolution Methods Database, Dronedarone $\mathrm{HCl}$ tablets, 2015., URL: https://www. accessdata.fda.gov/scripts/cder/dissolution/dsp_getallData. cfm (30. 8. 2019.).

17. Y. Zhang, M. Huo, J. Zhou, A. Zou, W. Li, C. Yao, S. Xie, DDSolver: An Add-In Program for Modeling and Comparison of Drug Dissolution Profiles, AAPS J. 12 (2010) 263-271, doi: https://doi.org/10.1208/s12248-010-9185-1

18. N. A. Peppas, J. J. Sahlin, A simple equation for the description of solute release. III. Coupling of diffusion and relaxation, Int. J. Pharm. 57 (1989) 169-172, doi: https://doi. org/10.1016/0378-5173(89)90306-2.

19. M. L. Bruschi, Mathematical models of drug release, u: Strategies to Modify the Drug Release from Pharmaceutical Systems, Elsevier, 2015., str. 63-86, doi: https://doi. org/10.1016/b978-0-08-100092-2.00005-9.

20. M. Grassi, G. Grassi, R. Lapasin, I. Colombo, Understanding drug release and absorption mechanisms: a physical and mathematical approach, 2007.

21. P. Costa, J. M. S. Lobo, Modeling and comparison of dissolution profile, Eur. J. Pharm. Sci. 13 (2001) 123-133, doi: https://doi.org/10.1016/S0928-0987(01)00095-1.

22. G. Matijašić, M. Gretić, J. Vinčić, A. Poropat, L. Cuculić, T. Rahelić, Design and 3D printing of multi-compartmental PVA capsules for drug delivery, J. Drug Deliv. Sci. Technol. 52 (2019) 677-686, doi: https://doi.org/10.1016/j. jddst.2019.05.037.

23. L. Kassaye, G. Genete, Evaluation and comparison of in-vitro dissolution profiles for different brands of amoxicillin capsules, Afr. Health Sci. 13 (2013) 369-75, doi: https://doi. org/10.4314/ahs.v13i2.25.

24. M. C. Makoid, A. Dufoure, U. V. Banakar, Modelling of dissolution behaviour of controlled release systems, S.T.P. Pharma Prat. 3 (1993) 49-58.

\section{SUMMARY \\ 3D-Printed Oral Dosage Forms Loaded with Dispersion of Oil and Active Ingredient \\ Andrea Milićević, Matija Gretić, and Gordana Matijašić*}

In this study, the possibility of producing pharmaceutical dosage forms by 3D printing technology is examined. In vitro dissolution tests were performed with printed dosage forms, and the results analysed in Microsoft Excel Add-In, DDSolver. 3D printing has provided six different models of solid dosage forms. The results of dissolution test have shown release profiles with initial time delay. The profiles are described by the Peppas-Sahlin model. It is shown that 3D printing technology has the potential to become a method for quick and simple production of personalized dosage forms with delayed release.

\section{Keywords}

3D print, personalized medicines, delayed release, release profiles, Peppas-Sahlin model

Faculty of Chemical Engineering and

Technology, University of Zagreb

Marulićev trg 19, 10000 Zagreb

Croatia
Original scientific paper

Received July 25, 2019

Accepted September 3, 2019 